(C) Цебренко А.В., 2020 p.

https://orcid.org/0000-0003-2144-392X

https://doi.org/10.34142/23128046.2020.48.13

А. В. Цебренко

\title{
НОРМАТИВНО-ПРАВОВЕ ВРЕГУЛЮВАННЯ ПРОЦЕДУРИ НАГОРОДЖЕННЯ ВЧИТЕЛІВ (ДРУГА ПОЛОВИНА ХІХ - ПОЧАТОК ХХ СТ.)
}

Стаття присвячена проблемі стимулювання діяльності вчителя, який перебував на державній службі на території України в другій половині XIX - початку XX cm. Розглядається один із найважливіших аспектів, а саме: нормативно-правове врегулювання нагородження та заохочення вчителів у досліджуваний період. 3'ясовано, що дана система носила складний та місиями заплутаний характер, оскільки мала иілий ряд труднощів та виключень.

Установлено, щзо порушене питання висвітлювалося у дослідженнях T. Среміної («Законодавча регламентачія системи нагороджень у навчальному відомстві в XIX - на початку XX ст.»), М. Вязьмітінова ("Система матеріального забезпечення та заохочення викладачів $i$ вчителів в освітніх установах імператорської Росії», «Відзнаки та медалі імператорської Росії за громадянські заслуги»), М. Винник («Усі вчительські нагороди»).

Під час дослідження, було звернено увагу на такий важливий вид винагороди як право вчителів здобути чин та звання особистого або родового дворянства, щзо було визначено нормами законодавства Російської iмnеріï.

Нагородження вчителів різних типів навчальних закладів було обумовлене нормами законодавства, щэо розвивалися впродовж XIX початку XX cm. у Російській імперії, воно мало поступовий характер $i$ в більшості випадків пов'язано з вислугою років на посаді. Важсливим фактором було те, щуо присудження винагороди зумовлювало надання прав $i$ привілеїв для вчителів, що у свою чергу давало можливість поліпшити їх матеріальне та суспільне положення.

Таким чином, у Російській імперії, зокрема й на території Украӥни, в другій половині XIX - на початку XX $\mathrm{cm}$. існувала розгалужена система нагород для вчителів, які знаходилися на державній службі. У иій системі було багато виключень, ще ускладнювала прочес нагородження гідних учасників навчального прочесу. Для вчителя кожен вид нагороди був кроком уперед для покращення свого соціального статусу, правового та матеріального положення. 
Важсливими для подальшого розгляду вважаємо проблему надання пільг вчителям як особливий різновид нагороди, щэо є неодмінною складовою системи стимулювання діяльності вчителя.

Ключові слова: вчитель, система нагород і заохочень, винагорода, класний чин, Міністерство народної освіти.

Tsebrenko A.V. Regulatory environment of the awarding teachers procedure (the second half of the XIX ${ }^{\text {th }}$ - the beginning of the $X X^{\text {th }}$ century). The article is devoted to the problem of stimulating the activity of teachers who were in public service on the territory of Ukraine in the second half of the XIX ${ }^{\text {th }}-$ the beginning of the $X X^{\text {th }}$ century. One of the most important aspects which is regulatory environment of the awarding and encouraging of teachers in the studied period is being considered. It has been found that this system was complex and sometimes undefined because it had a number of difficulties and exceptions.

It has been established that the raised issue was covered in the researches of T. Yeremina ("Legislative Regulation of the System of Awarding in the Educational Department in the XIX ${ }^{\text {th }}$ - the Beginning of the XX ${ }^{\text {th }}$ Century"), M. Viazmitinov ("System of Material Support and Encouragement of Teachers in Educational Institutions of Russia", "Awards and Medals of Imperial Russia for Civil Service"), M. Vynnik ("All Teacher's Awards").

In the study, attention has been drawn to such an important type of awarding as the right of teachers to obtain the rank and title of a personal or tribal nobleman, which was determined by the laws of the Russian Empire.

It has been established that the awarding of teachers of different types of educational institutions was due to the norms of the legislation that were developed during the XIX ${ }^{\text {th }}$ - the XX $X^{\text {th }}$ century in the Russian Empire, it was gradual and in most cases related to time in service. An important factor was that the awarding led to the granting of rights and privileges to teachers, which in turn made it possible to improve their financial and social status.

Thus, there was an extensive system of awards for teachers' public service in the Russian Empire, including the territory of Ukraine, in the second half of the $X I X^{\text {th }}$ - the beginning of the $X X^{\text {th }}$ century. There were many exceptions in this system, which made it difficult to award decent participants of the educational process. For teachers, each type of awarding was a significant step forward in improving their social status, legal and financial position.

We consider the problem of providing benefits to teachers as a special kind of awarding important for the further consideration, which is an indispensable part of the system of stimulating teachers' activity.

Keywords: teacher, system of awarding and encouraging, reward, class rank, Ministry of Public Education.

Вступ. У сучасних умовах модернізації української системи освіти підвищуються вимоги до вчителів, до їхньої професійної підготовки та 
особистісних якостей. Зауважимо, що в Рекомендаціях спеціальної міжурядової конференції ЮНЕСКО (05.10.1966 р.), яка займалася питаннями визначення статусу вчителів, наголошено: «Вчитель повинен мати відповідний статус, а професія вчителя має бути оточена суспільною пошаною» (Rekomendacija JuNESKO «O polozhenii uchitelej», 1966).

Зазначимо, що на підставі аналізу та узагальнення поглядів науковців під статусом учителя слід розуміти сукупність прав та обов'язків, які визначають його становище в суспільстві взагалі, та правове становище зокрема. Для того, щоб домогтися стійкої статусної позиції вчителя, необхідна підтримка від держави та надання нею високої оцінки педагогічної праці. Однією з форм такої оцінки $є$ сформована розгалужена система нагород для педагогічних працівників. Зокрема, в Законі України «Про освіту» від 05.09.2017 p. зроблено наголос на тому, що педагогічні працівники повинні бути нагородженими за особливі трудові заслуги державними нагородами (ст. 57).

3 огляду на це є доцільним звернутися до системи стимулювання професійної діяльності вчителів у другій половині XIX - на початку XX ст., складовою якої була й розгалужена система нагород та привілеїв для працівників (вчителів), які знаходилися на дійсній службі в державних установах, що підпорядковувалися Міністерству народної освіти. Адже, як зазначалося у збірнику законів Російської імперії: «Віддані слуги Государя й Вітчизни мають сподіватися на особливе Монарше благовоління і милість, й у всіх випадках ... чекати відповідної заслугам винагороди» (Trofimov, 1916).

Установлено, що порушене питання висвітлювалося у дослідженнях Т. Ереміної («Законодавча регламентація системи нагород у навчальному відомстві у XIX -початок XX ст.»), М. Вязьмітінова («Система матеріального забезпечення та заохочення викладачів і вчителів в освітніх установах імператорської Росії», «Відзнаки та медалі імператорської Росії за громадські заслуги»), М. Винник («Усі вчительські нагороди...»)).

Мета та завдання. Мета статті - виявити і схарактеризувати нормативно-правові основи нагородження вчителів в Україні у другій половині XIX - на початку XX ст.

Методи дослідження. Для розв'язання висунутої мети та завдань використовувалися такі методи наукового пізнання, як: аналіз, синтез, порівняння, класифікація, узагальнення - 3 метою аналізу змісту першоджерел, визначення вихідних теоретико-методологічних позицій та 
3'ясування нормативно-правових основ нагородження вчителів в Україні у другій половині XIX - на початку XX ст.

Результати. Проведений науковий пошук дозволяє стверджувати, що заохочення працівників у цілому, й вчителів, зокрема, у другій половині XIX - на початку XX ст. на території України залежало від керівництва та його неупередженого рішення. Так, у «Положенні про службові нагороди» від 31 липня 1859 р. (закон № 34781) було зазначено, що: «3 метою заохочення до служби, керівництво зобов'язане не залишати без подання до нагород осіб, що відрізнялися особливою старанністю» (Trofimov, 1916).

Аналіз урядових постанов та розпоряджень, що були прийняті протягом другої половини XIX - початку XX ст. («Збірник Законів та урядових розпоряджень, що стосуються домашніх наставників, наставниць, вчителів, вчительок й правила отримання першого класного чину, винагород та пенсій», «Нагородження орденами та іншими відзнаками», «Статут про службу», «Правила нагород, затверджені 1-го серпня 1898 р.», тощо), дозволив установити такі різновиди урядової підтримки вчителів, які знаходилися на державній службі в Міністерстві народної освіти, як-от: 1) присудження чину, що «надавало право на посаду й користування привілеями» (Eremina, 2009); 2) дарування звання; 3) власне нагороди (ордена, медалі й ін.); 4) подарунки; 5) одноразові грошові виплати; 6) визнання керівництва; 7) пільги.

Зазначимо, що «чин та Табель про ранги» - найважливіші складові суспільного життя Росії кінця XIX - початку XX століття. Порядок надання та підвищення чину було закріплено спеціальним розділом 3 Статуту «Про службу за призначенням від уряду». Проведений науковий пошук дозволяє стверджувати, що основною статтею за якою надавали відповідний чин вислуга за роками. Загалом, ті особи, які мали чин з XII - VIII класи, отримували право на присудження наступного через три роки, а чин VII - V класи - через чотири роки. Зазначимо, що отримати чин було можливо не тільки за вислугою років, але й за «службові відзнаки» (Eremina, 2010).

Щороку (до 1 липня) до керівництва навчальних округів надавали списки, в яких зазначалися особи, що заслуговують на заохочення. Варто зазначити, що кожна особа, яка претендувала на підвищення чину, повинна була надати певний перелік документів та відомостей (метричні данні про народження та хрещення; диплом, атестат або свідоцтво на вчительське звання (за наявності)). Також кандидат повинен був надати відгук від колишнього роботодавця, за умови, якщо запит на підвищення в чині було 
ініційовано керівником попереднього місця роботи вчителя. Зауважимо, що право на присудження чину мали вчителі чоловічих гімназій та прогімназій, жіночих гімназій та прогімназій, що користувалися правами вчителів чоловічих гімназій (Eremina, 2009).

Варто зазначити, що отримати кожен наступний чин можливо було лише послідовно. Відомості про присудження відповідного чину вчителю завжди висвітлювалися в урядових журналах та газетах того часу, зокрема, у «Журналі Міністерства народної освіти», «Вістях 3 народної освіти» тощо. Отримання чину впливало на положення вчителя в суспільстві, обумовлювало його більш високий соціальний статус. За наявності посадових або кримінальних злочинів учителя позбавляли чину за рішенням суду.

Установлено, що чільне місце серед нагород, як різновиду стимулювання діяльності вчителя в Україні, посіло присудження йому родового або особистого почесного громадянина, що надавало особі деякі пільги. Зокрема, вчителі з міщан, які завершили навчання в учительській семінарії та отримали звання особистого почесного громадянина, звільнялися від сплати грошових зборів. Так, як отримання звання не було нагородою у вигляді «Монаршої милості» (що надавалася Урядовим Сенатом), то така нагорода не виключала можливість отримати інші відзнаки до закінчення трирічного терміну. Наприклад, за ст. 35 «Правил про нагороди» від 1 серпня 1898 р., особи, що отримали звання особистого почесного громадянина мали право одержати позачергово срібну медаль на Володимирській стрічці (Eremina, 2010).

Зауважимо, що після 20-ти річної бездоганної служби, вчителі, які здобули освіту у вчительських семінаріях, мали можливість отримати звання особистого почесного громадянина. Після 25-ти річної служби їм присуджувалося звання родового почесного громадянина.

Під час аналізу збірки законів установлено, що домашні вчителі та наставники мали можливість отримати почесне звання «Заслужений наставник», якщо виконували свої обов'язки протягом 25-ти років і за цей період підготували щонайменше три особи, які вступили до університету.

Установлено, що суттєве місце у системі нагород вчителів у другій половині XIX - на початку XX ст. займали ордени, медалі, нагрудні знаки, якими нагороджували педагогічних працівників «За бездоганну службу та старанність» (Eremina, 2010). У переліку орденів, якими нагороджували 
вчителів були: Орден Святого Станіслава, Орден Святої Анни, Орден Святого рівноапостольного князя Володимира.

Аналіз законодавчої бази дає підстави стверджувати, що отримати орден мали право працівники, які знаходилися на цивільній службі, за умови наявності посади й чину не нижче $\mathrm{X}$ класу. Виключенням, було обіймання посад по «вченій та навчальній частині». Зазначені працівники повинні були мати чин не нижче IX класу, незалежно від займаної посади (ст.167) (Uchrezhdenie ordenov i drugih znakov otlichija, 1879).

М. Вязмітінов у своєму дослідженні зазначав, що провінційним учителям та навіть директорам училищ і гімназій було складно отримати орден високого порядку. Причинами цього дослідник уважав: по-перше, незначна кількість осіб серед вчительського складу мала високий чин; подруге, нагороди залежали не стільки від якості роботи, а більше - від благовоління керівництва; по-трете, отримання ордену було пов'язано 3 грошовими витратами, адже передбачало одноразовий внесок (сума внеску визначалася Статутом про нагороди). Окрім цього, орден низького порядку був певним захистом від «розбавлення дворянського стану недворянськими елементами». У своєму дослідженні М. Вязьмітінов зазначив, що до початку $\mathrm{XX}$ ст., «звання дворянина більш легко було отримати за наявності ордену, ніж відповідного чину». У період з 1882 по 1896 pp. 72\% осіб було затверджено в правах родового дворянства, й лише $28 \%$ - по чину (Vjaz'mitinov, 2017).

Виявлено, що право на нагороду мали й учителі, що бездоганно виконували свою роботу протягом багатьох років. Наприклад, за 15 років бездоганної служби, яку обов'язково потрібно було засвідчити документами у Міністерстві народної освіти, домашніх наставників нагороджували Орденом Св. Анни 3 ст., домашні вчителів - орденом Св. Володимира 4 ст. Зауважимо, що у досліджуваний період святкування ювілеїв не було приводом для отримання нагород. Вчитель, якого нагороджували орденом отримував права особистого дворянства та пенсійне забезпечення. Право дворянства надавалося за умови, якщо особа до цього моменту його не мала.

У переліку засобів стимулювання діяльності вчителів у другій половині XIX - на початку XX ст. було передбачено право висунення кандидатів на отримання золотих та срібних медалей, які присуджували за бездоганну службу. На цих медалях було викарбовано напис «За старанність». Право отримати медаль мали педагогічні працівники (зокрема, домашні вчителі та наставники) лише після 10-ти річної бездоганної служби 
за клопотанням керівництва. Домашніх наставників нагороджували золотими медалями на Олександрійській стрічці, вчителів та вчительок (за даними А. Пругавіна) срібною - на Олександрійській стрічці (Prugavin, 1898). Зазначимо, що цей вид нагород не надавав привілеїв для їх власників.

Установлено, що у лютому 1913 р. на честь 300-річчя царювання дому Романових було викарбовано ювілейну нагрудну медаль. Право носити іï мали як вчителі, так і вчительки, що працювали у середніх та нижчих за рівнем навчальних закладах. Пізніше це право отримали вчителі приватних шкіл, що користувалися правами навчальних закладів, які існували за рахунок держави. Усім вищезазначеним категоріям учителів надавалося свідоцтво на право носіння медалі, яке вони здобували за власний рахунок (Eremina, 2010).

Заслуговують на увагу й подарунки, якими нагороджували вчителів 3 метою стимулювання їхньої діяльності. У досліджуваний період виявлено два різновиди подарунків: особливий - 3 ім'ям Імператора та звичайний. Учитель, який отримував особливий подарунок, мав право отримати гроші в розмірі цінової вартості речі. За даними урядових часописів, у 1851 році звичайними подарунками були нагороджені старші вчителі: Волинської Гімназії - Криловський; Київської Другої Гімназії - Бєлоусов; молодші вчителі Київської Першої Гімназії - Корнаковський, Месонье (Eremina, 2009).

Аналіз часопису «Журнал Міністерства Народної Освіти» свідчить, що у другій половині XIX - на початку XX ст. одним із дієвих засобів стимулювання діяльності вчителів було надання одноразової грошової допомоги. Підставою для іiі вручення було свідчення про бездоганну службу, й про виконання обов'язків із «завзяттям та старанністю» (Zhurnal Ministerstva Narodnogo Prosveshhenija, 1851).

Виявлено, що у 1859 p. із метою заохочення до професійного самовдосконалення набуває поширенню практика відправлення вчителів за межі країни. Зазначимо, що така подорож передбачала або наукову мету або відпустку (за хворобою) й обов’язково здійснювалася за наказами, що підписував імператор. Наприклад, у часописі «Журнал Міністерства Народної Освіти» за 1859 рік знаходимо відомості про відрядження за кордон (наказ підписаний Імператором Олександром II від 1 квітня 1859 р.): «Надати відпустку за кордон старшому вчителю Харківської першої гімназії, титулованому раднику Шейдть (з 1 червня по 1 вересня 1859 р.)» (Zhurnal Ministerstva Narodnogo Prosveshhenija, 1859). 
Обговорення. Проведене дослідження дозволяє стверджувати, що в другій половині XIX - на початку XX століття існувала більш варіативна система підтримки вчителів, які знаходилися на державній службі в Міністерстві народної освіти. До основних видів нагороди належали: присудження чину; дарування звання; ордена, медалі й ін.; цінні подарунки; одноразові грошові виплати; моральне заохочення; різноманітні пільги.

Висновки. Таким чином, у Російській імперії, зокрема й на території України, в другій половині XIX - на початку XX ст. існувала розгалужена система нагород для вчителів, які знаходилися на державній службі. У цій системі було багато виключень, що ускладнювала процес нагородження гідних учасників навчального процесу. Для вчителя кожен вид нагороди був кроком уперед щодо покращення свого соціального статусу, правового та матеріального положення.

Важливою для подальшого розгляду вважаємо проблему надання пільг учителям як особливий різновид нагороди, що є неодмінною складовою системи стимулювання діяльності вчителя

\section{ЛІТЕРАТУРА:}

Вязьмитинов М. Н. Система материального обеспечения и поощрения преподавателей и учителей в образовательных учреждениях императорской России. Вестник УлГТУ. 2017. №2 (78). C. 4-14.

Еремина Т. Законодательное регулирование гражданского чинопроизводства учителей в XIX начале XX века. Известия РГПУ им. А.И. Гериена. 2009. №87. С. 139-148.

Еремина T. Законодательная регламентация системы награждений в учебном ведомстве в XIX - начале XX веков. Общество. Среда. Развитие (Terra Humana). 2010. №2. C. 94-97.

Пругавин А. С. Законы и справочные сведения по начальному народному образованию. СПб.: О.Н. Попова, 1898.785 с.

Трофимов Н. Н. Высочайшие награды. Петроград, 1916. 169 с.

Учреждение орденов и других знаков отличия. СПб.: Тип. Второго отд. соб. Е. и. в. канцел., 1876. 224 с.

Журнал Министерства Народного Просвещения. СПб.: Императорская Академия Наук. 1851. Ч. LXX. 798 c.

Журнал Министерства Народного Просвещения. СПб.: Императорская Академия Наук. 1859. Ч. LXX. 1000 c.

Рекомендация ЮНЕСКО «О положении учителей» (Принята 05.10.1966 Специальной межправительмтвенной конференцией по вопрсоу о статусе учителей). - Режим доступу: http://ppt.ru/newstext.phtml?id=50954

\section{REFERENCES:}

Vjaz'mitinov, M. N. (2017). Sistema material'nogo obespechenija i pooshhrenija prepodavatelej $i$ uchitelej $v$ obrazovatel'nyh uchrezhdenijah imperatorskoj Rossii. [The system of material support and encouragement of teachers and teachers in educational institutions of imperial Russia]. Vestnik UlGTU. №2 (78). P. 4-14. (in Russian). 
Eremina, T. (2009). Zakonodatel'noe regulirovanie grazhdanskogo chinoproizvodstva uchitelej v $X I X$ nachale $X X$ veka. [Legislative regulation of civilian production of teachers in the 19th and early 20th centuries]. Izvestija RGPU im. A.I. Gercena. 87. P. 139-148. (in Russian).

Eremina, T. (2010). Zakonodatel'naja reglamentacija sistemy nagrazhdenij $v$ uchebnom vedomstve $v$ XIX - nachale XX vekov. [Legislative regulation of the award system in the educational institution in the XIX - early XX centuries]. Obshhestvo. Sreda. Razvitie (Terra Humana). 2. P. 94-97. (in Russian).

Prugavin, A.S. (1898). Zakony $i$ spravochnye svedenija po nachal'nomu narodnomu obrazovaniju. [Laws and reference information on primary public education]. SPb.: O.N. Popova. (in Russian).

Trofimov, N. N. (1916). Vysochajshie nagrady. [Highest rewards]. Petrograd. (in Russian).

Uchrezhdenie ordenov $i$ drugih znakov otlichija. (1879). [The establishment of orders and other insignia.]. CPb.: Tip. Vtorogo otd. sob. E. i. v. kancel. (in Russian).

Zhurnal Ministerstva Narodnogo Prosveshhenija. (1851) [Ministry of Education Magazine]. $\mathrm{SPb}$.: Imperatorskaja Akademija Nauk. Ch. LXX. (in Russian).

Zhurnal Ministerstva Narodnogo Prosveshhenija. (1859) [Ministry of Education Magazine]. $\mathrm{SPb}$.: Imperatorskaja Akademija Nauk. Ch. LXX. (in Russian).

Rekomendacija JuNESKO «O polozhenii uchitelej» (1966, October, 5). [UNESCO Recommendation on the Status of Teachers]. Retrieved from: http://ppt.ru/newstext.phtml?id=50954 (in Russian).

\begin{tabular}{|c|c|}
\hline Інформація про автора: & Information about the author: \\
\hline Цебренко Альона Вячеславівна: & Tsebrenko Alona Viacheslavivna: \\
\hline ORCID:https://orcid.org/0000-0003-2144- & ORCID:https://orcid.org/0000-0003-2144- \\
\hline 392X; аспірантка кафедри історії педагогіки & 392X; Ph.D. candidate of Department of \\
\hline порівняльної педагогіки Харківського & History of Pedagogy and Comparative \\
\hline національного педагогічного університету & Pedagogy H.S. Skovoroda Kharkiv National \\
\hline $\begin{array}{l}\text { імені Г. С. Сковороди, вул. Валентинівська, } \\
2, \text { м. Харків, Україна, } 61166\end{array}$ & $\begin{array}{l}\text { Pedagogical University, Valentynivska street, } \\
\text { 2. Kharkiv, Ukraine, } 61166\end{array}$ \\
\hline e-mail: alenacebrenco & mail: alenacebrenco@gmail.com \\
\hline
\end{tabular}

Цитуйте цю статтю як: Цебренко А.В. Нормативно-правове врегулювання процедури нагородження вчителів (друга половина XIX - початок XX ст.). Теорія та методика навчання та виховання. 2020. № 48. С. $146-154$.

DOI: https://doi.org/10.34142/23128046.2020.48.13

Дата надходження статті до редакції:

Стаття прийнята до друку: 